medRxiv preprint doi: https://doi.org/10.1101/2021.05.20.21257343; this version posted May 24, 2021. The copyright holder for this preprint (which was not certified by peer review) is the author/funder, who has granted medRxiv a license to display the preprint in perpetuity.

It is made available under a CC-BY-NC-ND 4.0 International license .

\title{
Attitudes Toward The COVID-19 Vaccine Among North Carolina Participants In The CoVID- 19 Community Research Partnership
}

Chukwunyelu H Enwezor, M.D. ${ }^{1}$, James E. Peacock, Jr. M.D. ${ }^{1}$, Sharon L Edelstein, ScM ${ }^{8}$, Amy N Hinkelman Ph.D. ${ }^{5}$, Austin L Seals, M.S. ${ }^{2}$, Thomas F Wierzba, Ph.D. ${ }^{1}$, Iqra Munawar' ${ }^{1}$, Patrick D Maguire, M.D. ${ }^{3}$, William H Lagarde, M.D.4, Michael S Runyon, M.D.7, Michael A Gibbs M.D.7, Thomas R Gallaher M.D. ${ }^{6},{ }^{*}$ John W. Sanders III, M.D., M.P.H. ${ }^{~}{ }^{*}$ David M. Herrington, M.D., M.H.S2*

1Department of Internal Medicine, Section on Infectious Diseases, Wake Forest School of Medicine, Winston-Salem, NC, 275157

2Department of Internal Medicine, Section on Cardiovascular Medicine, Wake Forest School of Medicine, Winston-Salem, NC, 27517

${ }^{3}$ New Hanover Regional Medical Center, Wilmington, NC, 28401

${ }^{4}$ Wake Med Health and Hospitals, Raleigh, NC, 27610

${ }^{5}$ Campbell University Jerry M. Wallace School of Osteopathic Medicine, Lillington, NC, 27546

6Vidant Health, Greenville, NC, 27834

${ }^{7}$ Atrium Health, Charlotte, NC, 28204

${ }^{8}$ Biostatistics Center, George Washington University Milken School of Public Health, Washington, DC

* Contributed equally.

Corresponding author:

Chukwunyelu H Enwezor, MD

Section on Infectious Diseases

Wake Forest University School of Medicine

Medical Center Blvd.

Winston Salem, NC 27157

cenwezor@wakehealth.edu

Running title: Vaccine hesitancy in NC

Keywords: Vaccine hesitancy, vaccine intent, COVID-19, survey, North Carolina

Word count: 2619 


\section{Abstract}

2 Willingness to receive the newly developed Coronavirus Disease-2019 (COVID-19) vaccines is

3 highly variable. To assess the receptiveness of a select sample of North Carolinians to COVID-19

4 vaccination, a brief survey was conducted among participants in the COVID-19 Community

5 Research Partnership (CCRP) affiliated with five medical centers in North Carolina. A total of

620,232 CCRP participants completed a multiple choice, mini survey electronically between

7 December 17, 2020 and January 13, 2021. Of the 20,232 survey respondents, $15,422(76.2 \%)$ were

8 receptive to vaccination. Vaccine receptiveness increased incrementally with age with those $>70$

9 years being the most willing to be vaccinated compared to all other age groups. Respondents with

10 no previous COVID-19 diagnosis were more likely to accept the vaccine compared to those that

11 have a previous COVID-19 diagnosis (76.6\% vs 60.9\%). Comparative analysis of gender,

12 race/ethnicity, and residence locale revealed that women, African Americans, and suburban

13 participants were less willing to get a COVID-19 vaccine. There was no difference in vaccine intent

14 based on healthcare worker status. Of those unwilling to get the vaccine, $82 \%$ indicated that the

15 reason was uncertainty about the safety and efficacy of the vaccine. 
medRxiv preprint doi: https://doi.org/10.1101/2021.05.20.21257343; this version posted May 24, 2021. The copyright holder for this preprint (which was not certified by peer review) is the author/funder, who has granted medRxiv a license to display the preprint in perpetuity.

It is made available under a CC-BY-NC-ND 4.0 International license .

\section{Introduction}

2 Since cases of COVID-19 were first reported in Wuhan, China in December 2019, various measures

3 like mask wearing and social distancing have been instituted by various countries $(1,2,3)$. Despite

4 these measures, there have been significant loss of lives and livelihoods. A lot of effort was put into

5 developing vaccines as the most effective means of stopping the virus. By April 2021, three COVID-

619 vaccines had been approved for Emergency Use Authorization (EUA) by the Food and Drug

7 Administration (FDA). About 200 million vaccines had been administered nationwide (6) and 6.7

8 million in the state of North Carolina (Error! Reference source not found.) as of April 22, 2021.

9 Despite the initial enthusiasm about vaccine availability, vaccine acceptance and willingness to undergo vaccination were not universal with some national surveys suggesting that only $50-55 \%$ of respondents would be willing to receive the COVID-19 vaccine (Error! Reference source not

12 found.,6). In North Carolina, some polls revealed intent at only 40-45\% (8).

13 To assess the extent of vaccine hesitancy in North Carolina, we conducted a survey between

14 December 17, 2020 and January 13, 2021 of 20,232 individuals affiliated with five medical centers

15 from differing geographic regions of North Carolina. This report presents the key findings from that 16 survey.

\section{Materials and Methods}

20 The CCRP is a multi-site, prospective study combining daily electronic symptom surveillance,

21 longitudinal serologic surveillance, and electronic health record capture. Demographic and survey

22 data was collected via a secure, HIPAA-compliant, online portal. The study has received approval by

23 centralized IRB (Wake Forest Baptist Health). Five of the sites participated in this sub-study. Those 
medRxiv preprint doi: https://doi.org/10.1101/2021.05.20.21257343; this version posted May 24, 2021. The copyright holder for this preprint (which was not certified by peer review) is the author/funder, who has granted medRxiv a license to display the preprint in perpetuity.

It is made available under a CC-BY-NC-ND 4.0 International license .

1 sites were Campbell University in Buies Creek, NC, New Hanover Regional Medical Center in

2 Wilmington, NC, Wake Forest Baptist Health in Winston-Salem, NC, WakeMed Health and Hospitals

3 in Raleigh, NC, and Vidant Health, in Greenville, NC.

4 Basic demographic data captured for all CCRP participants included age, sex, previous COVID-19

5 diagnosis status, community of residence, and race/ethnicity. Counties of residence were

6 characterized as urban, suburban, or rural utilizing the North Carolina rural center counties map.

7 Densities were calculated based on the 2014 census population estimates (9). Participants were

8 also classified as to whether they were healthcare workers with all healthcare-related vocations

9 and disciplines included in that category. In addition to their daily CCRP surveys, participants were

10 asked to complete a single multiple-choice mini-survey on attitudes about COVID-19 vaccination ${ }^{1}$.

11 There were four choices for vaccine intent: yes, no, undecided, and prefer not to answer. For

12 participants who did not respond "yes" to the vaccine intent question, a follow-up question asked

13 participants to specify reasons for vaccine hesitancy (Fig 1). The survey was sent daily from

14 December 17, 2020 until January 13, 2021. Once a response was documented electronically, the

15 mini survey was deleted from further daily surveys to ensure that each participant responded only

16 once.

17 To correlate the association of demographic characteristics with vaccine intent, binomial regression was implemented. Vaccine intent responses were categorized into two groups for this analysis: Yes and No/Undecided. To assess how demographic characteristics were associated with vaccine

20 receptiveness, multivariate binomial regression was used with a log link function. The resulting

21 coefficient estimates were exponentiated $\left(\mathrm{e}^{\mathrm{b}}\right)$ to calculate relative risk. The relative risk of

22 responding 'Yes' was calculated for each demographic variable, along with 95\% confidence

23 intervals. Previous COVID-19 Diagnosis was self-reported information included as a part of the

24 enrollment questionnaire. The impact of a prior diagnosis of COVID-19 on vaccine receptiveness

\footnotetext{
${ }^{1}$ See supplemental data for questionnaire.
} 
1 was also analyzed in a similar fashion. P-values $<0.001$ were considered significant. All statistical

2 analysis was conducted using SAS 9.4 (SAS Institute, Cary, NC).

\section{$4 \quad$ Results}

5 A total of 20,232 people completed the mini survey (Campbell University, $n^{2}=147$; New Hanover

6 Regional Medical Center, $n=641$; Wake Forest Baptist Health, $n=16058$; Wake-Med Health and

7 Hospitals, $n=2419$; and Vidant Health, $n=967)$. Most respondents were White (90\%), female (68\%),

8 and most were $<60$ years old (median age 50 years with range 18 to 80 ). Non-healthcare workers

9 comprised $74 \%$ of the total respondents. Only $2.4 \%(n=476)$ of participants had a previous COVID-

1019 diagnosis. Across all demographics, 76.2\% of participants expressed intent to get the vaccine

11 (Table 1).

12 Compared to men, women were less likely to indicate a willingness to undergo vaccination [82.6\%

13 vs $73.2 \%$ adjusted $\mathrm{RR}=0.92,95 \% \mathrm{CI}(0.91,0.93), \mathrm{P}<0.0001]$ (Table 2$)$. Vaccine receptiveness

14 increased incrementally with age, with those $>70$ years the most likely to accept the vaccine

15 compared to each of the other age categories (Table 1).

${ }^{2} n$ - Number of participants 
medRxiv preprint doi: https://doi.org/10.1101/2021.05.20.21257343; this version posted May 24, 2021. The copyright holder for this preprint (which was not certified by peer review) is the author/funder, who has granted medRxiv a license to display the preprint in perpetuity.

It is made available under a CC-BY-NC-ND 4.0 International license .

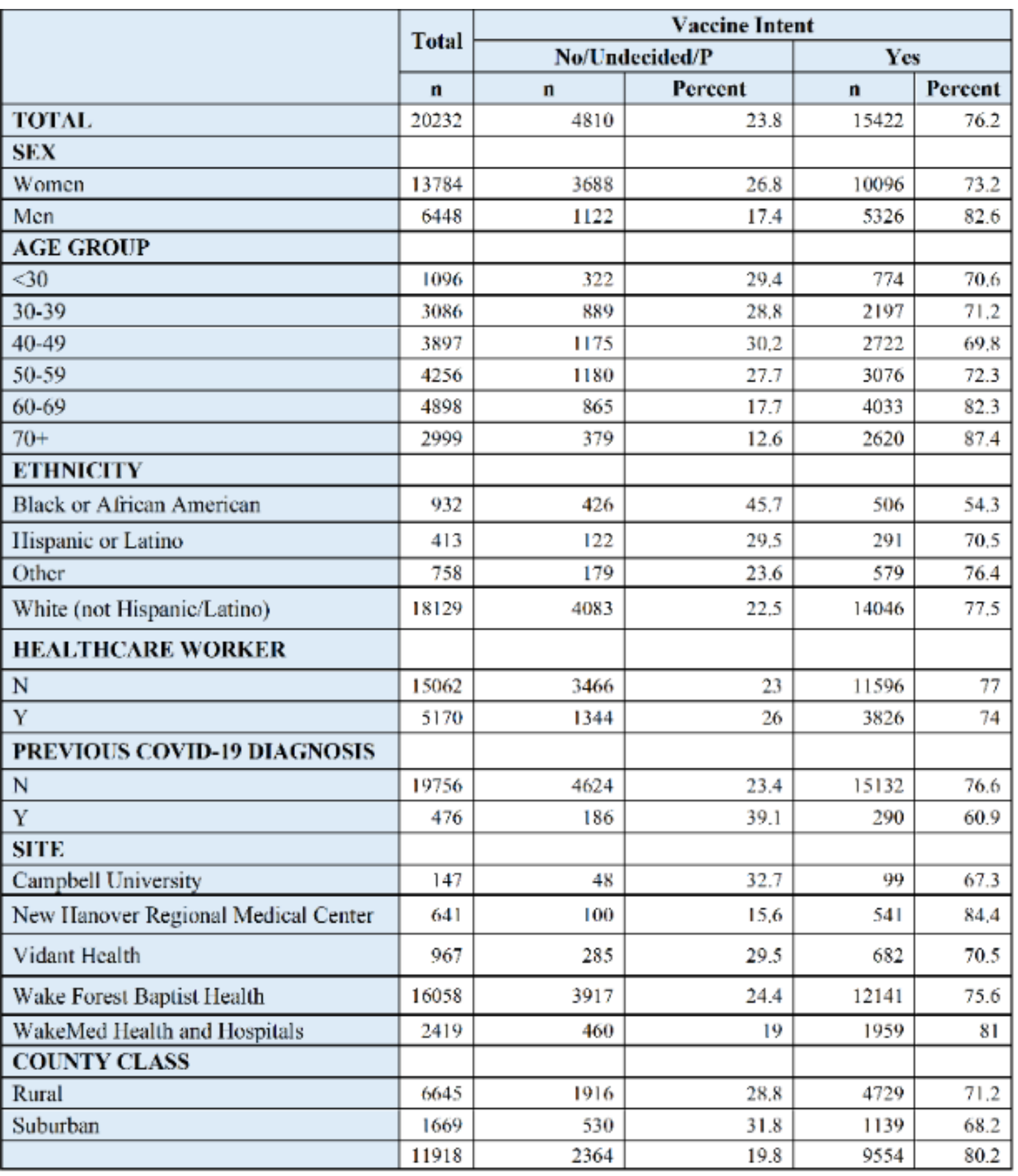

Table 1. Vaccine intent responses grouped by sex, age, race \& ethnicity, healthcare worker status, previous COVID-19 diagnosis, Site and county class. $\mathrm{n}$ - no; $\mathrm{P}-$ prefer not to answer; $\mathrm{N}-\mathrm{no}$; $\mathrm{Y}$ - yes. 
1 African Americans were the least willing to accept the vaccine at 54.3\%, compared to all other

2 groups; Hispanic or Latino (70.5\%), other (76.4\%) and White (77.5\%) (Adjusted RR 1.31,1.41 and

31.39 respectively $\mathrm{p}<0.0001)$

4 Respondents without a previous COVID-19 diagnosis were more likely to accept the vaccine

5 compared to those that have a previous COVID-19 diagnosis (76.6\% vs 60.9\%, adjusted RR 1.20 ,

$695 \% \mathrm{CI}(1.11,1.28), \mathrm{p}<0.0001)$

$7 \quad$ When stratifying response by county residence, suburban and rural residents were less likely than

8 urban residents to accept the vaccine. Suburban residents were the least likely to accept the

9 vaccine (68\%) as compared to urban residents (81\%) (Adjusted RR 0.85, 95\% CI $(0.83,0.88$ ), $\mathrm{p}<0.0001$ ). The vaccine acceptance rate of rural residents was $71.2 \%$.

11 Interestingly, healthcare workers were somewhat less likely to accept the vaccine compared to

12 non-healthcare workers [74\% vs 77\%] (Table 1), a difference that remained statistically significant

13 in a multivariate analysis $(\mathrm{p}=0.0014)$ (Table 2). 
medRxiv preprint doi: https://doi.org/10.1101/2021.05.20.21257343; this version posted May 24, 2021. The copyright holder for this preprint (which was not certified by peer review) is the author/funder, who has granted medRxiv a license to display the preprint in perpetuity.

It is made available under a CC-BY-NC-ND 4.0 International license .

Table 2. Vaccine acceptance multivariate and type 3 analysis grouped by sex, age, race \& ethnicity, healthcare worker status, previous COVID-19 diagnosis, Site and county class.

$\mathrm{n}$ - no; $\mathrm{P}$ - prefer not to answer; $\mathrm{N}$ - no; $\mathrm{Y}$-yes; $\mathrm{Cl}$ - Confidence interval; ChiSq-Chi square

\begin{tabular}{|c|c|c|c|c|c|c|}
\hline \multicolumn{7}{|c|}{ Vaccine Acceptance Multivariate Model Estimates } \\
\hline \multirow{2}{*}{$\begin{array}{l}\text { Parameter } \\
\text { SEX }\end{array}$} & \multirow[b]{2}{*}{ Women } & \multirow{2}{*}{$\begin{array}{r}\text { Estimate } \\
-0.07\end{array}$} & \multirow{2}{*}{$\begin{array}{c}\begin{array}{c}\text { Adj. } \\
\text { Relative } \\
\text { Risk }\end{array} \\
0.93\end{array}$} & \multicolumn{2}{|c|}{$\begin{array}{c}\text { Relative } \\
\text { Risk 95\% } \\
\text { CI }\end{array}$} & \multirow{2}{*}{$\begin{array}{r}\text { Pr }>\text { ChiSq } \\
<.0001 \\
\end{array}$} \\
\hline & & & & 0.92 & 0.94 & \\
\hline & Men & ref. & ref. & ref. & ref. & \\
\hline \multirow[t]{6}{*}{ AGE GROUP } & $<\mathbf{3 0}$ & -0.17 & 0.85 & 0.81 & 0.88 & $<.0001$ \\
\hline & 30-39 & -0.16 & 0.85 & 0.83 & 0.87 & $<.0001$ \\
\hline & $40-49$ & -0.17 & 0.84 & 0.82 & 0.86 & $<.0001$ \\
\hline & $50-59$ & -0.15 & 0.86 & 0.84 & 0.88 & $<.0001$ \\
\hline & $60-69$ & -0.03 & 0.97 & 0.95 & 0.98 & 0.0001 \\
\hline & $>=70$ & ref. & ref. & ref. & ref. & . \\
\hline \multirow[t]{4}{*}{ ETHNICITY/RACE } & $\begin{array}{l}\text { Hispanic or } \\
\text { Latino }\end{array}$ & 0.27 & 1.31 & 1.20 & 1.42 & $<.0001$ \\
\hline & Other & 0.34 & 1.41 & 1.32 & 1.51 & $<.0001$ \\
\hline & $\begin{array}{l}\text { White (not } \\
\text { Hispanic/Latino) }\end{array}$ & 0.33 & 1.39 & 1.31 & 1.48 & $<.0001$ \\
\hline & $\begin{array}{l}\text { Black or African } \\
\text { American }\end{array}$ & ref. & ref. & ref. & ref. & \\
\hline
\end{tabular}


medRxiv preprint doi: https://doi.org/10.1101/2021.05.20.21257343; this version posted May 24, 2021. The copyright holder for this preprint (which was not certified by peer review) is the author/funder, who has granted medRxiv a license to display the preprint in perpetuity.

It is made available under a CC-BY-NC-ND 4.0 International license .

7 Among the 4,810 individuals who indicated that they did not intend to get vaccinated or were

8 undecided, the most common reasons were concerns about safety (67\%) and efficacy (15\%) (Fig

9 1). An important point to note is that of the participants that did not respond "yes" to the vaccine, more than half were undecided ${ }^{3}$.

Fig. 1

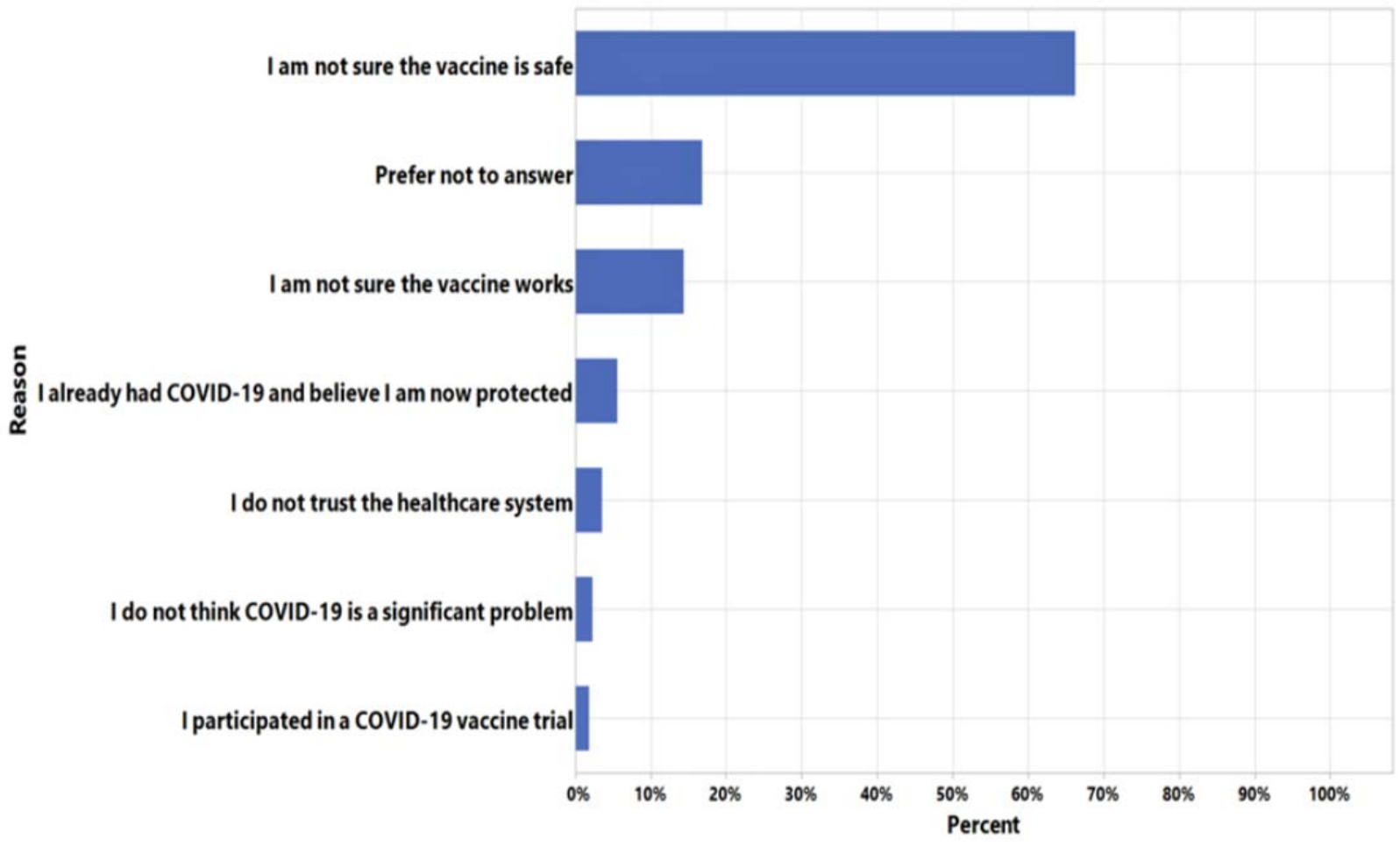

${ }^{3}$ Supplemental data. Table 3 
medRxiv preprint doi: https://doi.org/10.1101/2021.05.20.21257343; this version posted May 24, 2021. The copyright holder for this preprint (which was not certified by peer review) is the author/funder, who has granted medRxiv a license to display the preprint in perpetuity.

It is made available under a CC-BY-NC-ND 4.0 International license .

Fig 1. Reasons given by participants that did not respond "yes" on the survey.

1 Discussion

2 This survey was designed to assess attitudes about vaccine acceptance among a cohort of North

3 Carolinians during the period immediately following EUA of the Pfizer and Moderna COVID-19

$4 \quad$ vaccines. Most participants in this study expressed willingness to receive a vaccine.

5 Previously published surveys have addressed vaccine hesitancy (6,7,12,Error! Reference source

6 not found.,13,13 ). The largest of these was a global study done in April 2020 involving 13,426

7 participants from 19 countries, including 773 participants in the US. Of the US participants, $75.2 \%$

8 of the respondents reported intent to get the vaccine $(10,13)$. A survey conducted by the CDC

9 between September and December of 2020 showed $68 \%$ of the participants reporting their intent

10 to undergo vaccination (11). A survey done by the Kaiser Family Foundation (KFF) in February

112021 , found only 55\% of respondents intending to get the vaccine (6). Another recent poll

12 conducted February 16-21 by Pew Research was headlined "growing share of Americans say they

13 plan to get a COVID-19 vaccine or already have". In this survey, $69 \%$ of the public intend to get the

14 vaccine, or had already received the vaccine. This finding compared to a similar poll conducted by

15 Pew in November 2020, is up by 19\% (12). Although the questions asked in these surveys were not

16 strictly comparable to ours, multiple surveys indicate between 50\%-75\% of respondents report an

17 intent or likely intent to get the vaccine.

18 Looking at the subgroups in our survey, the strongest independent predictor of COVID-19 vaccine

19 hesitancy is Black race. This is particularly important to note because racial and ethnic minority

20 groups, have disproportionately been affected by COVID-19. Despite Black Americans making up

21 just $12.5 \%$ of the US population, an October 2020 CDC report showed that $18.7 \%$ of COVID-19 cases

22 were Black Americans (14). In another report, it was noted that the mortality rate among Black 
medRxiv preprint doi: https://doi.org/10.1101/2021.05.20.21257343; this version posted May 24, 2021. The copyright holder for this preprint (which was not certified by peer review) is the author/funder, who has granted medRxiv a license to display the preprint in perpetuity. It is made available under a CC-BY-NC-ND 4.0 International license .

1 Americans is 2 -fold higher than Whites (15). In Black American communities and other minority

2 populations, mistrust of the healthcare system due to inequities in access and prior adverse

3 experiences with medical research has been the main reason for hesitancy $(16,17)$. On local, state

4 and national levels, there have been various interventions aimed at achieving an equitable vaccine

5 campaign and decreasing hesitancy in Black, Indigenous and People of Color (BIPOC) communities

6 in the United States. Grassroot community partnerships and educational programs like "train-the-

7 trainer" led by the COVID-19 Prevention Network (CoVPN) of the National Institute of Allergy and

8 Infectious Diseases (NIAID) and on a national level, guidance provided by the current

9 administration based on 5 key principles: iteration, involvement, information, investment and

10 integration, may have helped decrease hesitancy in the Black American community since our

11 survey was conducted(18,19). Recent surveys show a trend in the Black community towards

12 vaccine acceptance $(20,21)$. On the other hand, resident locale has now become a stronger predictor

13 of vaccine hesitancy with residents of rural counties least likely to accept the COVID-19 vaccine

$14(21,23,23,25)$. This shift may be related to political and religious affiliations $(25,27)$. In our survey,

15 it was interesting to note that suburban residents were the least likely to accept the vaccine

$16(68.2 \%)$, compared to rural $(71.2 \%)$ and urban residents $(80.2 \%)$. While many reports of vaccine

17 hesitancy among rural residents nationally have been noted, this is the first survey that shows more

18 hesitancy among suburban residents. North Carolina rural residents are significantly more

19 accepting of the COVID-19 vaccine when compared to national data from a KFF survey in January

202021 , which showed only 31\% of rural respondents had intent to get the COVID-19 vaccine (23).

21 Other independent predictors of hesitancy to get the COVID-19 vaccine in our survey are younger

22 adults, female gender and having a previous COVID-19 diagnosis. Among younger adults,

23 misconceptions about risk for adverse outcomes from COVID-19 infection and uncertainty of

24 vaccine effectiveness may be the primary barriers to vaccine acceptance (26). Women are less

25 likely to accept the vaccine in the survey. Other surveys show that safety and efficacy of the 
medRxiv preprint doi: https://doi.org/10.1101/2021.05.20.21257343; this version posted May 24, 2021. The copyright holder for this preprint (which was not certified by peer review) is the author/funder, who has granted medRxiv a license to display the preprint in perpetuity.

It is made available under a CC-BY-NC-ND 4.0 International license .

1 vaccines are the primary reasons for hesitancy (27). The implications of this could potentially be

2 significant because studies have shown that women make approximately $80 \%$ of the healthcare

3 decisions for their families (28). Participants with previous COVID-19 diagnosis are less likely to

4 accept the vaccine because they believe they are protected (Fig 1). A study looking at immune

5 memory generated after COVID-19 infection showed retained immunity at $\sim 6$ months (29). This

6 immunity wanes over time. Hence, the CDC has recommended COVID-19 vaccination be offered to

7 individuals that have recovered from the infection following good safety data from clinical trials

8 (30). Finally, for all groups, poor availability of scheduling information, lack of internet access,

9 inability to take time off from work, and/or transportation difficulties which preclude travel to

10 vaccination sites may also need to be addressed (31).

11 An interesting group in this survey are healthcare workers. Healthcare workers in this survey

12 include, all healthcare related vocations and disciplines, clinical staff members, support staff and

13 pharmacies. Healthcare workers trended towards not accepting the vaccine when compared to

14 non-healthcare worker (74\% v 77\%). Although, this goes contrary to what we should expect,

15 similar attitudes have been reflected in other surveys $(32,33)$. This is relevant because healthcare

16 workers can transmit confidence in the vaccine to the communities that they serve thereby

17 increasing vaccine uptake.

18 Among participants in the survey that did not indicate an intent to get the COVID-19 vaccine, more

19 than half (56\%) of the respondents were undecided because of uncertainty of efficacy and safety.

20 This informs us that there is an opportunity to address the concerns this group of individuals have.

21 The CDC "Vaccinate with Confidence" national strategy (34) provides a framework for public health

22 officials and advocacy groups to reinforce confidence in vaccines:

$23-$ Build trust.

24 - Empower healthcare personnel. 
medRxiv preprint doi: https://doi.org/10.1101/2021.05.20.21257343; this version posted May 24, 2021. The copyright holder for this preprint (which was not certified by peer review) is the author/funder, who has granted medRxiv a license to display the preprint in perpetuity.

It is made available under a CC-BY-NC-ND 4.0 International license .

- $\quad$ Engage communities and individuals.

2 These strategies should be targeted to the underlying reasons for vaccine hesitancy specific to

3 groups undecided or unwilling to pursue vaccination. A “before we attempt to persuade, try to

4 understand" approach may yield better success in communities less willing to be vaccinated (34).

5 There are several potential limitations of this study. First, our data represent responses from

6 respondents in North Carolina enrolled into an ongoing research study through regional healthcare

7 systems and may not be representative of national data. Our volunteers are likely to be better

8 connected to a healthcare system and more comfortable with electronic communication than the

9 general community. Second, this survey provides a snapshot in time during the early rollout of the vaccines, and attitudes may have changed with more recent nationwide and local interventions to

11 address hesitancy. Third, the demographics of our survey participants may not reflect national

12 demographics. Fourth, our finding of more hesitancy among suburban residents may simply reflect

13 limitations in our method for characterizing counties as it is difficult to accurately describe many

14 counties in North Carolina as entirely urban, suburban, or rural. Finally, survey results might not

15 be comparable to other national or state polls or surveys due to potential differences in survey methods, sample population, and questions related to willingness to get the vaccine.

17 In conclusion, in this survey of participants in North Carolina from mid-December 2020 to January

18 2021, a large majority indicated intent to undergo COVID-19 vaccination. Our survey results

19 suggest that vaccination hesitancy may be a potential impediment to a successful vaccination

20 campaign, especially among several subgroups. Opportunities exist to target those subgroups with

21 focused educational interventions and other support in the hope of increasing vaccine acceptance.

22 Further work is planned to assess changing attitudes about COVID-19 vaccination. 


\section{Abbreviations:}

BIPOC - Blacks, Indigenous and People of color

COVID-19 - Coronavirus disease 2019

11 NIAID - National Institute of Allergy and Infectious Diseases

12 SARS-CoV-2 - severe acute respiratory syndrome coronavirus-2

16 Author Contributions: C.E. served as lead author. A.S contributed to the analysis of the results

17 J.P., J.S., D.H., A.H, S.E., T.W., I.M., P.M., M.G., M.R., W.L., S.H., all contributed to the design and

18 implementation of the research, and to the writing of the manuscript.

19 All authors have read and approved the final manuscript. 
medRxiv preprint doi: https://doi.org/10.1101/2021.05.20.21257343; this version posted May 24, 2021. The copyright holder for this preprint (which was not certified by peer review) is the author/funder, who has granted medRxiv a license to display the preprint in perpetuity.

It is made available under a CC-BY-NC-ND 4.0 International license .

1 Funding: This work was supported by the Coronavirus Aid, Relief, and Economic Security (CARES)

2 Act by the U.S. Department of the Treasury.

3

$4 \quad$ Institutional Review Board Statement: The study was conducted according to the guidelines of

5 the Declaration of Helsinki and approved by the Institutional Review Board of Wake Forest School

6 of Medicine Institutional Review Board, protocol [IRB00064912].

7 Informed Consent Statement: Informed consent was obtained from all subjects involved in the

8 study.

9

Data Availability Statement: The datasets used and/or analyzed during the current study are

11 available from the corresponding author upon request.

12

Acknowledgements:

COVID-19 Community Research Partnership Study Group:

Wake Forest School of Medicine

Mark A. Espeland PhD, Morgana Mongraw-Chaffin PhD, Alain Bertoni MD, Martha A. Alexander-

17 Miller PhD, Allison Mathews PhD, MS, Brian Ostasiewski, Christine Ann Pittman Ballard MPH

George Washington Biostatistics Center

19 Diane Uschner PhD, Michele Santacatterina PhD, Greg Strylewicz PhD, Brian Burke MS, Mihili

20 Gunaratne MPH, Meghan Turney MA, Shirley Qin Zhou MS

\section{Atrium Health}

22 , MPH, Lewis H. McCurdy MD, Yhenneko Taylor PhD, Lydia Calamari MD, Hazel Tapp PhD, Amina

23 Ahmed MD, Michael Brennan DDS, Lindsay Munn PhD, RN, Tim Hetherington MS, Lauren Lu, 
medRxiv preprint doi: https://doi.org/10.1101/2021.05.20.21257343; this version posted May 24, 2021. The copyright holder for this preprint (which was not certified by peer review) is the author/funder, who has granted medRxiv a license to display the preprint in perpetuity.

It is made available under a CC-BY-NC-ND 4.0 International license .

1 Connell Dunn, Melanie Hogg MS, CCRA, Andrea Price, Mariana Leonidas, Laura Staton, Kennisha

2 Spencer MPH, Melinda Manning, Whitney Rossman MS, Frank Gohs MS, Anna Harris MPH, Bella

3 Gutnik MS, Jennifer Priem PhD, MA

4 MedStar

$5 \quad$ Kristen Miller DrPH, CPPS, William Weintraub MD, Chris Washington, Allison Moses, Sarahfaye

6 Dolman, Julissa Zelaya-Portillo, John Erkus, Joseph Blumenthal, Romero Barrientos, Ronald E,

7 Sonita Bennett, Shrenik Shah, Shrey Mathur, Christian Boxley, Paul Kolm, Long La, Cheng Zhang, Eva

8 Hochberger, Ella Franklin, Deliya Wesley, Naheed Ahmed

9 University of Maryland School of Medicine - Baltimore

10 Karen Kotloff MD, Wilbur Chen MD, MS, DeAnna Friedman-Klabanoff MD, Andrea Berry MD, Helen

11 Powell, $\mathrm{PhD}$

Tulane University

13 Joseph Keating PhD, Patricia Kissinger PhD, Richard Oberhelman MD, John Schieffelin MD, Joshua

14 Yukich PhD, Andrew “AJ” Beron MPH, Devin Hayes BS, Johanna Teigen MPH

U of Mississippi

Adolfo Correa MD, PhD, Leandro Mena MD, MPH, Bhagyashri Navalkele MD, Yuan-I Min MD,

17 Alexandra Castillo MPH, Lori Ward PhD, MS, Robert P. Santos MD, Courtney Gomillia MS-PHS,

18 Pramod Anugu, Yan Gao MPH, Jason Green, Ramona Sandlin RHIA, Donald Moore MS, Lemichal

Drake, Dorothy Horton RN

WakeMed Health and Hospitals, LaMonica Daniel BSCR

21 New Hanover Regional Medical Center, Lynette McFayden, RN 
medRxiv preprint doi: https://doi.org/10.1101/2021.05.20.21257343; this version posted May 24, 2021. The copyright holder for this preprint (which was not certified by peer review) is the author/funder, who has granted medRxiv a license to display the preprint in perpetuity.

It is made available under a CC-BY-NC-ND 4.0 International license.

\section{Vidant Health}

2 Thomas Gallaher, MD, Michael Zimmer, PhD Danielle Oliver, Tina Dixon

\section{Campbell University}

4 , Robin King-Thiele DO, Terri S. Hamrick PhD, Chika Okafor MD, Regina B. Bray Brown MD,

5 Pinoorma Vinod MD

6

7 Conflicts of Interest: The authors declare no conflict of interest. The funders had no role in the

8 design of the study; in the collection, analyses, or interpretation of data; in the writing of the

9 manuscript, or in the decision to publish the results. 
medRxiv preprint doi: https://doi.org/10.1101/2021.05.20.21257343; this version posted May 24, 2021. The copyright holder for this preprint (which was not certified by peer review) is the author/funder, who has granted medRxiv a license to display the preprint in perpetuity.

It is made available under a CC-BY-NC-ND 4.0 International license .

\section{References}

1. Archived: WHO timeline - COVID-1927 April 2020. Available at: Vaccinations NC $\underline{\text { DHHS COVID-19 }}$

2. Dweepobotee Brahma, Sikim Chakraborty, and Aradhika Menokee. The early days of a global pandemic: A timeline of COVID-19 spread and government interventions; Brookings institute, April 2, 2020.

3. COVID-19 dashboard by the center for system science and engineering at John Hopkins University of Medicine. Available at: https://coronavirus.jhu.edu/map.html

4. United States COVID-19 Cases and Deaths by State maps, charts, and data provided by the_CDC. Available at: https://covid.cdc.gov/covid-datatracker/\#cases casesper100klast7days

5. NCDHHS dashboard. Available at:https://covid19.ncdhhs.gov/dashboard/vaccinations

6. Liz Hamel. Kaiser Family Foundation (KFF); KFF COVID-19 vaccine monitor: February 2021.

7. Salvanto, Jennifer De Pinto, Fred Backus and Kabir Khanna. Many would get the COVID-19 vaccine, but hesitancy remains- CBS news poll. Anthony February 26, 2021.

8. Jason Debruyn. Polls Show North Carolinians Are Increasingly Willing to Get COVID19 Vaccine By • FEB 16, 2021.

9. NC rural center. Available at: About us page; https://www.ncruralcenter.org/aboutus /

10. Jeffrey V. Lazarus et al. A Global Survey of Potential acceptance of a COVID-19 Vaccine. Nature medicine. Vol 27. February 2021. 225-228 
medRxiv preprint doi: https://doi.org/10.1101/2021.05.20.21257343; this version posted May 24, 2021. The copyright holder for this preprint (which was not certified by peer review) is the author/funder, who has granted medRxiv a license to display the preprint in perpetuity.

It is made available under a CC-BY-NC-ND 4.0 International license .

11. Kimberly Nguyen et al. COVID-19 Vaccination Intent, Perceptions, and Reasons for Not Vaccinating Among Groups Prioritized for Early Vaccination — United States, September and December 2020; MMWR February 9.2021. 70(6). 217-222

12. Gary Funk and Alec Tyson. Growing Share of Americans Say They Plan to Get a COVID19 Vaccine - or Already Have-77\% think vaccinations will benefit U.S. economy; Pew Center research science and society, March 05,2021.

13. Jagdish Khubchandani et al. COVID-19 Vaccination Hesitancy in the United States: A Rapid National Assessment; Journal of community health. January 03, 2020

14. Jeremy Gold et al. Race, Ethnicity, and Age Trends in Persons Who Died from COVID19 - United States, May-August 2020. MMWR / October 23, 2020 / 69(42);15171521

15. The color of coronavirus: COVID-19 deaths by race and ethnicity in the U.S. APM research lab staff, March 5, 2021. Available at :https://www.apmresearchlab.org/covid/deaths-by-race

16. Michael A. Fletcher. New poll shows Black Americans see a racist health care system setting the stage for pandemic's impact even as they lose family members and jobs, most are reluctant to try a vaccine; Undefeated, November 2020.

17. Lonnae 0’Neal. Half of Black adults say they won't take a coronavirus vaccine. Undefeated, November 2020

18. Sandra Quinn, Ph.D and Michele Andrasik PhD. Addressing Vaccine hesitancy in BIPOC communities - toward trustworthiness, partnership, and reciprocity. March 31, 2021. DOI: $10.1056 /$ NEJMp2103104

19. Equity in vaccination: A plan to work with communities of color toward COVID-19 recovery and beyond. Working group on equity in COVID-19 vaccination. John Hopkins school of public health, centerforhealthsecurity.org. February 2021 
medRxiv preprint doi: https://doi.org/10.1101/2021.05.20.21257343; this version posted May 24, 2021. The copyright holder for this preprint (which was not certified by peer review) is the author/funder, who has granted medRxiv a license to display the preprint in perpetuity.

It is made available under a CC-BY-NC-ND 4.0 International license .

20. Juana Summers. Little difference in vaccine hesitancy among White and Black Americans, poll finds. npr.org. March 12, 2021

21. Curtis Bunn. 'Getting a clearer picture': Black Americans on the factors that overcame their vaccine hesitancy. NBC news. April 12, 2021.

22. Emmarie Huetteman, Covid vaccine hesitancy drops among all Americans, new survey shows. KHN. March 30.2021

23. Sarah Jane Tribble. Rural Americans, Who Doubted the Pandemic, Now Hesitant to Get Vaccinated. March 14, 2021

24. Ashley Kirzinger, Cailey Manana and Mollyann Brodie; Vaccine hesitancy in Rural America: KFF Jan 07, 2021.

25. Isaac Stanley-Becker, Lena Sun. Vaccine restrictions vanish in pockets of the U.S., offering a glimpse of the future. March 18, 2021

26. Jennifer Welsh. Why young adults say they won't get a COVID-19 vaccine. Verywellhealth. March 05, 2021.

27. Timothy Callaghan et al. Correlates and disparities of intention to vaccinate against COVID-19. Social science and medicine. 4 January 2021. 113638

28. Sabrina Matoff-Stepp. Women as health care decision-makers: implications for health care coverage in the United States. Journal of healthcare for the poor and undeserved. 25(2014): 1507-1513

29. Jennifer Dan et al. Immunological memory to SARS-CoV-2 assessed for up to 8 months after infection. Science 05 feb 2021. Vol 371, issue 6529

30. Summary document for interim clinical considerations for use of COVID-19 vaccines currently authorized in the United States. CDC 04/09/2021 
31. Agency for healthcare research and quality. 2018 national healthcare quality and disparities report. Available at: https://www.ahrq.gov/research/findings/nhqrdr/nhqdr18/index.html

32. KFF and Washington Post Frontline health care workers survey. March 2021. Available at: https://www.washingtonpost.com/context/washington-post-kfffrontline-health-care-workers-survey-feb-11-march-7-2021/ba15a233-9495-47a99cdd-e7fa1578b1ca/

33. Vaccine hesitancy among health care workers raises concerns. WBTV, NC watchdog reporting network. April 9,2021.

34. Building Confidence in COVID-19 Vaccines among your patients. Tips for healthcare teams. Developed by the CDC COVID-19 task force. January 2021; https://www.cdc.gov/vaccines/covid-19/downloads/VaccinateWConfidenceTipsForHCTeams 508.pdf

35. Lisa Rosenbaum, MD. Escaping Catch-22- Overcoming COVID-19 vaccine hesitancy; Feb 12, 2021, NEJM.

16


TOTAL

SEX

Women

Men

AGE GROUP

$<30$

30-39

$40-49$

$50-59$

60-69

$70+$

\section{ETHNICITY}

Black or African American

Hispanic or Latino

Other

White (not Hispanic/Latino)

HEALTHCARE WORKER

$\mathrm{N}$
$\mathrm{Y}$

PREVIOUS COVID-19 DIAGNOSIS

$\mathrm{N}$

$\mathrm{Y}$

\section{SITE}

Campbell University

New Hanover Regional Medical Center

Vidant Health

Wake Forest Baptist Health

WakeMed Health and Hospitals

COUNTY CLASS

Rural

Suburban

\begin{tabular}{|c|c|c|c|c|}
\hline \multirow{3}{*}{$\frac{\text { Total }}{\mathrm{n}}$} & \multicolumn{4}{|c|}{ Vaccine Intent } \\
\hline & \multicolumn{2}{|c|}{ No/Undecided/P } & \multicolumn{2}{|c|}{ Yes } \\
\hline & $\mathbf{n}$ & Percent & $\mathbf{n}$ & Percent \\
\hline 20232 & 4810 & 23.8 & 15422 & 76.2 \\
\hline 13784 & 3688 & 26.8 & 10096 & 73.2 \\
\hline 6448 & 1122 & 17.4 & 5326 & 82.6 \\
\hline 1096 & 322 & 294 & 774 & 706 \\
\hline 3086 & 889 & 28.8 & 2197 & 71.2 \\
\hline 3897 & 1175 & 30.2 & 2722 & 69.8 \\
\hline 4256 & 1180 & 27.7 & 3076 & 72.3 \\
\hline 4898 & 865 & 17.7 & 4033 & 82.3 \\
\hline 2999 & 379 & 12.6 & 2620 & 87.4 \\
\hline 932 & 426 & 45.7 & 506 & 54.3 \\
\hline 413 & 122 & 29.5 & 291 & 70.5 \\
\hline 758 & 179 & 23.6 & 579 & 76.4 \\
\hline 18129 & 4083 & 22.5 & 14046 & 77.5 \\
\hline 15062 & 3466 & 23 & 11596 & 77 \\
\hline 5170 & 1344 & 26 & 3826 & 74 \\
\hline 19756 & 4624 & 23.4 & 15132 & 76.6 \\
\hline 476 & 186 & 39.1 & 290 & 60.9 \\
\hline 147 & 48 & 32.7 & 99 & 67.3 \\
\hline 641 & 100 & 15.6 & 541 & 84.4 \\
\hline 967 & 285 & 29.5 & 682 & 70.5 \\
\hline 16058 & 3917 & 24.4 & 12141 & 75.6 \\
\hline 2419 & 460 & 19 & 1959 & 81 \\
\hline 6645 & 1916 & 28.8 & 4729 & 71.2 \\
\hline 1669 & 530 & 31.8 & 1139 & 68.2 \\
\hline 11918 & 2364 & 19.8 & 9554 & 80.2 \\
\hline
\end{tabular}


Vaccine Acceptance Multivariate Model Estimates

\begin{tabular}{|c|c|c|c|c|c|c|}
\hline Parameter & & Estimate & $\begin{array}{l}\text { Adj. } \\
\text { Relative } \\
\text { Risk }\end{array}$ & \multicolumn{2}{|c|}{$\begin{array}{c}\text { Relative } \\
\text { Risk 95\% } \\
\text { CI }\end{array}$} & Pr $>$ ChiSq \\
\hline \multirow[t]{2}{*}{ SEX } & Women & -0.07 & 0.93 & 0.92 & 0.94 & $<.0001$ \\
\hline & Men & ref. & ref. & ref. & ref. & \\
\hline \multirow[t]{6}{*}{ AGE GROUP } & $<\mathbf{3 0}$ & -0.17 & 0.85 & 0.81 & 0.88 & $<.0001$ \\
\hline & 30-39 & -0.16 & 0.85 & 0.83 & 0.87 & $<.0001$ \\
\hline & $40-49$ & -0.17 & 0.84 & 0.82 & 0.86 & $<.0001$ \\
\hline & $50-59$ & -0.15 & 0.86 & 0.84 & 0.88 & $<.0001$ \\
\hline & $60-69$ & -0.03 & 0.97 & 0.95 & 0,98 & 0.0001 \\
\hline & $>=70$ & ref. & ref. & ref. & ref. & \\
\hline \multirow[t]{4}{*}{ ETHNICITY/RACE } & $\begin{array}{l}\text { Hispanic or } \\
\text { Latino }\end{array}$ & 0.27 & 1.31 & 1.20 & 1.42 & $<.0001$ \\
\hline & Other & 0.34 & 1.41 & 1.32 & 1.51 & $<.0001$ \\
\hline & $\begin{array}{l}\text { White (not } \\
\text { Hispanic/Latino) }\end{array}$ & 0.33 & 1.39 & 1.31 & 1.48 & $<.0001$ \\
\hline & $\begin{array}{l}\text { Black or African } \\
\text { American }\end{array}$ & ref. & ref. & ref. & ref. & \\
\hline \multirow[t]{2}{*}{ HEALTHCARE WORKER } & $\mathbf{N}$ & -0.03 & 0.97 & 0.96 & 0.99 & 0.0014 \\
\hline & $\mathbf{Y}$ & ref. & ref. & ref. & ref. & \\
\hline \multirow[t]{2}{*}{ PREVIOUS COVID-19 DIAGNOSIS } & $\mathbf{N}$ & 0.18 & 1.20 & 1.11 & 1.28 & $<.0001$ \\
\hline & $\mathrm{Y}$ & ref. & ref. & ref. & ref. & \\
\hline \multirow[t]{3}{*}{ COUNTY CLASS } & Rural & -0.10 & 0.90 & 0.89 & 0.92 & $<.0001$ \\
\hline & Suburban & -0.16 & 0.85 & 0.83 & 0.88 & $<.0001$ \\
\hline & Urban & ref. & ref. & ref. & ref. & \\
\hline
\end{tabular}


Fig. 1

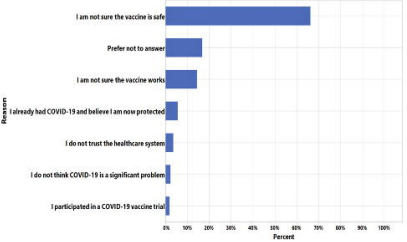

